\title{
The View of Practice of Marx and Its Realistic Significance
}

\author{
Xiaorong $\mathrm{Mi}^{*}$ and Mao Lin \\ Institute of Marxism, Southwest University, Chongqing, China
}

\begin{abstract}
In the philosophical theory system of Marx, practice is a fundamental category that occupies the primary position. It is through constructing scientific view of practice that Marx realized his transformation of the philosophical paradigm. Thus, a correct understanding of the practice category of Marx is of extremely important realistic significance.
\end{abstract}

Keywords: Marx, view of practice, realistic significance

\section{Historical Observation on the Notion of Practice}

Although the philosophical thoughts prior to production of Marxism philosophy contain some commendable thoughts and reasonable elements, essentially speaking, they have not formed a complete and scientific notion of practice. Observation on the view of practice of Marx has to begin with sprout of Marxism philosophy and its growth environment, whereas western philosophy tradition is exactly the soil for its growth. Hence, explanation of Marx's notion of practice, of course, has to be placed in the tradition of western practical philosophy.

Considering the historical process of western philosophy development, its development can be approximately classified into three stages, namely, ancient Greece - modern times - contemporary times (Zhang Rulun, 1995, p.215).

First of all, the ancient Greek times was represented by Aristotle. In the ancient Greece, "practice" primarily denoted the behavioral pattern of a general living thing in the most general sense. It is generally believed that ever since Aristotle, practice was really brought into the category of philosophy. Moreover, Aristotle constructed the first practical philosophy theory in the history of philosophy on that basis and initiated the tradition of western practical philosophy, being the founder of western practical philosophy. Aristotle classified human activities into three parts: theory, practice and production. Theory is a kind of meditating and speculative activity and is the highest practice. It mainly takes its own as the

\footnotetext{
${ }^{*}$ Corresponding author
}

purpose of activity and theory per se is the purpose of itself. Instead, it is not a means used to attain other purposes. It mainly includes economics, ethics and politics. By contrast, practice mainly denotes ethical and moral activities, and its activity object is not the nature without will, but human being, a kind of ethical conduct and political activity in the broad sense between human beings. It reflects the relations between self and others. Thus, its object and purpose are consistent in that both of them are human itself. Production is to generate a thing according to the principle of the nature. That is, it denotes production and technical activities, especially production activities of material subsistence. Its object is a thing without will and its final purpose denotes the activity result outside itself, so it is a kind of means or instrument ( $\mathrm{Li}$ Wenge, 2005). Therefore, the trichotomy of Aristotle can be summarized on the basis of self-sufficiency and freedom of activities as practice and production since theory fails under the category of practice and both of them are activities with themselves being the purpose. Practice is a flower without fruit, because flowering per se is the purpose. By contrast, production has to bear a fruit, whereas flowering is nothing more than a means. Moreover, he thought that the ultimate goal of practice was kindness related with happiness and this kindness was the ethical morality and political behavior of human being distinguished from production and labor, which is a kind of correct behavior. In the eyes of Aristotle, "Ethical behavior originates from a kind of free living style, and freedom originates from politics", and "the ultimate meaning of life is free activities" (Zhang, Rulun, 
1995, p.115). Therefore, as a matter of fact, Aristotle defines practice as interpersonal relationship and behavior with value and moral significance, namely, ethical and moral behavior.

The second stage is the modern times represented by Kant and Hegel, which is a period of evolution of western view on practice. The changes occurring to the notion of practice during this period were closely connected with the social development background at that time. On one hand, the fundamental function of production in social development became increasingly prominent. On the other hand, scientism at that time propagated its belief on a large scale and the consequence of scientization would necessarily lead to decline and fall of the notion of traditional practice. "Thus, the notion of technology takes the place of the notion of practice. In other words, the judgment capacity of experts takes the place of political rationality" (HansGeorg Gadamer, 2007, p.739). The notion of practice during this period more "surpassed" than inherited Aristotle's notion of practice, and the most representative figure was Hegel. In the eyes of Hegel, truth was unification of theory and practice and practice was no longer relative to production or technology (technique), but, instead, contained production and technical activities. Practice in this way is "production" or "technology". A practical activity is from the subject to the object and the objective world is nothing more than a collection of countless accidental facts and illusory patterns and an illusion. In contrast, human being resorts to the subjective and internal essence to transform this accidental collection, which is aimed at "the purpose and interest" of the subject and making the world transformed as "supposed to be in this way" with the will of the subject. However, a theoretical is exactly the opposite. It is from the object to the subject and to enter from the extant objective world to the subjective thinking of human being. It is aimed at perceiving the world "as it is in this way". In the eyes of Hegel, unification is achieved between the theoretical idea and the practical idea. Of course, practice Hegel here mentions is nothing more than a kind of psychogenic labor instead of a kind of substantial and perceptual activity. Although Hegel emphasizes the positive role of labor in the formation of human being in his "Phenomenology of Mind", he merely regards the practical labor (material production practice) as a stage in the process of selfconsciousness and self-recognition of the absolute.
Therefore, in his comprehension, labor is a kind of spiritualization labor (Hegel, 1979, pp. 146-151).

It is true that production labor has occupied the mainstream of modern practice thoughts, but the view of practice of Aristotle was still followed by Kant. Moreover, Kant made critique on the view of practice that was popular in the times when scientism prevailed. He didn't regard such material practical activities as labor as an activity field that was suitable for the free man or confine practice to the aspect of moral activity. Instead, he believed that there existed two kinds of practice, namely, technical practice and moral practice, which were not equal. In the eyes of Kant, theoretical philosophy was a rule that was established on the basis of causal natural concept and on the condition perception and that was practical in terms of technology. Moral practice was a rule that was totally established on the basis of the free concept and on the condition of super-perception and that was practical in terms of morality. Just because of this, Kant laid a foundation for the revival path of contemporary philosophy of practice.

The third stage started approximately from the $60 \mathrm{~s}$ in the 20th Century with evolution of the notion of practice represented by Hans-Georg Gadamer and Habermas. In fact, this stage is the contemporary revival of the philosophy of practice and the emergence of this revival had its profound theoretical and practical reasons. Theoretically speaking, the revival was exploration made by philosophers during this period to seek for solutions of philosophical crisis and was reflection and subversion on the speculative philosophy that broke away from the reality of life. Practically speaking, the revival was reflection on a series of problems existing in the transition of human society from the industrial civilization to the post-industrial civilization. On one hand, European and American developed capitalism countries which took the lead in entering the industrial civilization, indeed, enjoyed the abundant material achievements brought by developed productivity and scientific and technological progress. On the other hand, these countries were also trapped into extremely great crisis, which was mainly spiritual worry caused by war, ecological damage, environmental pollution and nuclear threat. Moreover, instead of getting liberation from the "civilization" in this developed industrial civilization, people in these countries fell into deeper alienation crisis. For example, Herbert Marcuse in the Frankfurt School made fierce critique on the post-industrial civilization society from the perspective of ideology 
in his publication "One Dimensional Man" published in 1964. He pointed out, the so-called civilization was nothing more than another kind of totalitarianism and in such a totalitarianism society, negativity, criticism and transcendence of people as well as the dissenting opinions in the society were all successfully repressed, as a result of which the society became a one dimensional society and man became a one dimensional man. Thus, contemporary philosophers recommended returning to the tradition of practical philosophy, awakening again people's rational reflection on their own behaviors and regaining their judgment on practice and "liberating" the production and technology practice (Li Wenge, 2005).

As one of the representatives at that time, HansGeorg Gadamer applied her practical hermeneutics to propose distinguishing technology and practice and advocate "social understanding theory", and thought that practice in its traditional sense was not the opposite of theory and that practice was a kind of existence pattern of man and a kind of theoretical and reflective activity that comprehends and confirms the essence of existence. As a contemporary leading figure of the Frankfurt School, Habermas put forward his practice of communication. He held the view that under the name of social labor, Marx attributed interaction to labor which was faced up with the issue of means and technology and interaction between different men was the issue of practice. The so-called "practice", in his eyes, put particular emphasis on the interaction activities between different men and stipulated labor as a kind of communication behavior. However, in the eyes of Habermas, restrained by a variety of factors, people who lived in the postindustrial civilization society were unable to communicate as a true self. Therefore, the consensus achieved in the communication was not the original intention of these people. In order to resolve the issue of true self, it was a must to get rid of all kinds of obstructions that restrained people's freedom of will and let them recover a real communication and achieve real understanding and consensus (Zhang Nengwei, 2012).

In a word, the contemporary philosophy of practice is aimed to get rid of the modern notion of production practice and to return to the practice tradition in ancient Greece. Just different from Aristotle, the founder of philosophy, the scope of practice in the contemporary philosophy of practice is broadened and encloses all kinds of interpersonal communication activities.

\section{Marx's View of Practice}

\section{Formation of Marx's view of practice}

Practice is the most fundamental category of Marx's philosophy and the most important and elementary concept in the philosophy of Marx. Marx's view of practice is the theoretical basis of the entire Marxism philosophy. Formation of Marx's thought on practice is a historical process with gradual development and its initial sprout ought to date back to his first PHD thesis 'On the Difference between Democritus' Natural Philosophy and Epicurus' Natural Philosophy". In this thesis, Marx mentioned, for the first time, "the view of practice" although "practice" he talked about at that time was nothing more than spiritual practice that broke away from the objective material. Later on, Marx came to realize the important role of production practice in social development during the period of his working in "Rheinische Zeitung" and "Yearbook of Germany and France", and from then on he had further understanding in practice. Marx's in-depth comprehension in practice should be during the period when he published "Economic \& Philosophical Manuscripts of 1844". In the "Manuscript", practice was relative to "theory", "conceptual life" and "reasonable re-presentation of self", while it was synonymous to labor, "realistic life" and "active and realistic re-presentation of self" (Ye Ruxian \& Li Huibin, 2006, pp.44-46). The final establishment of Marx's view of practice was during his creation of "Outline of Feuerbach's Theory" and "The German Ideology", when Marx transferred from construction of time within the scope of spirit to construction of time on the basis of social production and labor, determining the core position of practice in the philosophy of Marxism (Li Ruobing, 2008).

Nonetheless, Marx hasn't given an explicit definition on the notion of practice, but research and reading of his works helps to approximately grasp his demarcation on the notion of practice. Just as has been mentioned before, prior to production of the philosophy of Marxism, either practice was comprehended as a kind of spiritual activity with creativity or practice was understood as a kind of material activities that had no distinction from animal activities. It was unlikely to unify the initiative and materiality of practice according to its inherent relationship. The main reason was that practice was understood without consideration of the production and labor of man. Marx discovered that production and labor was the most fundamental practical activity 
of man, and production and labor not only reflected the initiative creation essence of man, but also fell within the scope of perceptual material activities. It is just in this way that Marx saw labor (production practice) as the foundation of all human practical activities, unified these two opposite features of labor together and finally defined a scientific notion of practice. Marxism philosophy considers practice the fundamental pattern of human survival and development and is particular objectivity perceptual activity of human being. And first of all, practice contains the need of human being to satisfy their own life in the future and the initiative material activities to use certain tools and take definite methods to change the external world. This notion has the following several basic characteristics (Ye Ruxian \& Li Huibin, 2006, pp.44-46).

Firstly, practice is the fundamental pattern of human survival and development and is a kind of objective, realistic and perceptual activity of man. In the eyes of Marx, the primary premise for human survival and all histories is the survival issue of mankind, namely, the material production activities of mankind to satisfy their own clothing, food and living. Marx pointed out, "This kind of activity, this consecutive perceptual labor and creation and this production is exactly the foundation of the extant perceptual world." (Central Compilation \& Translation Bureau, 1995, pp.7-10). Thus, production practice not only brings up mankind, but also is the basis for mankind to get developed.

Secondly, practice is perceptual and objective activity of objectivity. Just as Marx said, "Not only the object but also the subject are produced by production"; "production not only produces an object for the subject, but also produces a subject for the object"; and "in the process of production, man is objectification and in the process of consumption, goods are subjectification" (Central Compilation \& Translation Bureau, 1995, pp.7-10). Therefore, according to Marx, practice was a realistic activity in which the subject and the object were mutually objectification and practice was neither an isolated and abstract self-movement of man nor a unidirectional process in which the will of man was imposed on the nature and the society. In the process of a practical activity, man the external world was the object of recognition and change of man and, in the meantime, the external world was also changing man. As the subject in the practical activity, man was an existence of objectivity (Chi Chaobo, 2002).
Thirdly, practice is a conscious and purposeful creative activity of mankind. Marx said, "The shoddiest architect is wiser than the most skillful honeybee at the very beginning in that he has also constructed the honeycomb in his mind before he constructs it with the beewax. The result obtained at the end of the labor process has been existing in the representation of the laborer at the very beginning of the process, that is, it exists conceptually." The activity of animals also has "perceptual" objectivity, but it is not time mainly because it is an instinctive action without any direction of thought or purpose. By contrast, the activity of man is with thought and rationality and man does not only make the object changed in terms of form in the process of labor, but also fulfills their own purpose in the object.

Fourthly, practice is a social and historical activity. The social and historical feature of practice is manifested in the fact that the power of practice of mankind is historically formed and developed. Just as the well-known physicist and philosopher Newton said, "If I have seen farther than the others, it is because I stand on the shoulders of giants." Man in each definite times can only begin their own activity on the basis of inheriting the practical achievements of their predecessors. Therefore, although practice can be manifested as an individual activity of a single person, man always has a relationship with the nature and conducts practical activities by means of a definite social relationship with historical development that is produced with the power of man.

In brief, in the eyes of Marx, practice was a particular survival and living style of man. It is through practice that material things and conceptual things were mutually converted which was the basis and bond that joined communicated about the relationship between the subject and the object. A practical activity not only reflected constraint of an object on man, but also manifested the initiative and independence of man in the object. In one word, it is exactly due to the scientific recognition of Marx in practice that the greatest revolutionary transformation was fulfilled in the history of philosophy. A scientific notion of practice is the core notion of Marxism philosophy.

\section{The Guiding Significance of Marx's View of Practice to the Current China Construction Practice}

Ever since the more than thirty years of reform and opening up in China, the governing party has correctly grasped the transition of the contemporary 
world theme, kept a foot in the basic national situation, used for reference the development experiences overseas, and guided the people at the level of practice to have the courage to practice and to be bold in practice. Finally, they have successfully taken a path of socialism with Chinese characteristics and formed the socialist theoretical system with Chinese characteristics.

\section{Marx's view of practice helps to better insist on human orientation}

Marx's view of practice regards practice as a social and historical process, in which man is the subject of practice and man always conducts practical activities in a certain social relationship so as to push forward social and historical development. The first principle of scientific outlook on development is development in which the core is human orientation. "Human" here in "human orientation" necessarily refers to "the realistic man" and "man in the practical activities", while "orientation" means the basis of human practical essence, that is, to make the social development more corresponding with the purpose of man to play the essence of their own practice and sufficiently occupy this basis.

Moreover, as the subject of social practice, only if man coordinates well the relationship between man and the nature and the society and the relationship between different men and take a highly responsible attitude towards the nature, the society and man per se, is it likely to really realize comprehensive, coordinated and sustainable development and to promote development of the entire human society and human themselves (Ni Zhi'an \& Li Likun, 2006).

\section{Marx's view of practice helps to construct a harmonious society}

The so-called harmonious society is to make an overall and comprehensive reflection on the cause of social construction in an overall thinking way, take an overall consideration of all aspects of economics, politics, society, culture and ecology and attain internal coordination and balance of all kinds of practical activities which constitute all components of the social organism. Marx's view of practice has provided us with important theoretical support and practical guidance to construct a harmonious society. Essentially speaking, the social organism is the condensation and manifestation of the objectification of human practical activities and deficiency or imbalance of any link in the practical activities may lead to incapacity of harmonious and orderly running of the social organism. For instance, without development of material production practice, "what remained would only be universality of poverty and extreme impoverishment; while under extreme impoverishment, it would be a re-starting of the struggle to strive for necessities and all old and decayed and stagnant things would rise from ashes again" (Central Compilation \& Translation Bureau, 1995, p86). However, if we merely cared about material production practice and ignored development of spiritual production practice, it would be inevitable that material production practice would lose the opportunity for long term development, which might cause tension between the relationship of man and the nature, and bring about the issues of "revenge on mankind" by the natural world, such as, environmental pollution and ecological crisis. As a result, man and the nature could not have got along in harmony. Thus, it is necessary to insist on Marx's view of practice and try to achieve internal balance of all kinds of practical activities, so as to construct a harmonious socialist society (Chu Jinguang, 2011).

\section{Marx's view of practice helps to resolve difficulties in contemporary human development}

In the contemporary times, with development of science and technology and productivity by leaps and bounds, indeed, the practical activities of mankind have created immeasurable achievements, but, in the meantime, have also brought about numerous crises to the external environment where mankind lives the natural world. In the face of the crises mankind is faced up with, Marx's view of practice has provided a scientific perspective for us to survey and ponder over difficulties encountered in the contemporary development. Practice is the essence of the social life and is the basis of differentiation and unification of man and the world. Therefore, it is necessary for us to comprehend difficulties encountered in the contemporary human development from the perspective of human practical activities. The practical activities of mankind can be approximately classified into two major categories: one is to change the natural world and the other is to change human society.

Thus, in the process of changing the natural world by mankind, it is a must to maintain balance of the natural system so as to protect the continuous and unbroken re-production of the natural world and 
realize harmonious unification of man and the nature (Chu Jinguang, 2011). Likewise, in the process of changing the society, it is also necessary for mankind to try to maintain the coordination and balance of the social community, regard the fundamental interest of socialist of the society and the entire human kind that represents the mainstream direction of human development as the highest standard, practically and fundamentally guarantee sustainable existence and re-production of the human social community and enable the social community to really become the existence that is favorable for its own survival and development.

All in all, the view of practice is the most central and fundamental category of Marxism philosophy. It is just on the basis of the view of practice that Marxism philosophy has surpassed all previous philosophical theories and has constituted a complete and rigorous theoretical system with integration of materialism and dialectics, integration of the view of the nature and the view of the history and integration of ontology and epistemology.

\section{References}

Central Compilation \& Translation Bureau. (1995). Karl Marx and Frederick Engels (Vol 1). Beijing: People's Publishing House, pp.7-10, 77, 86.

Chi, Chaobo. (2002). On the Marx's view of practice. Marxism and Reality, (3).

Chu, Jinguang. (2011). Study on Marx's view of practice, Master Thesis. Shanghai: Shanghai Normal University.

Hans-Georg Gadamer. (2007). Truth and Method. Beijing: The Commercial Press, p.739.

Hegel. (1979). Phenomenology of Mind (Volume 1). Beijing: The Commercial Press, pp. 146-151.

Li, Ruobing. (2008). Historical Study and Comparison of the Notion of Practice. Heilongjiang Social Sciences, (6).

Li, Wenge. (2005). A "Contradiction" in Marx's View of Practice. Philosophical Researches, (5).

$\mathrm{Ni}$, Zhi'an, \& Li, Likun. (2006). Insisting on the practical outlook on development "Human Orientation. Probe, (5).

Ye, Ruxian, \& Li, Huibin. (2006). Modern Interpretation of Marxism Practical Philosophy, Vol. 9, Beijing: Social Sciences Academic Press, pp.44-46.

Zhang, Nengwei. (2012). Practical philosophy: Confluence vision and comparative comprehension of Gadamer and Marxism philosophy. Journal of Anhui University (Philosophy and Social Sciences), (11).

Zhang, Rulun. (1995). History and Practice. Shanghai: Shanghai People's Publishing House, p.215. 